\title{
Serum estrogen receptor bioactivity and breast cancer risk among postmenopausal women
}

\author{
Vanessa W Lim, Jun Li, Yinhan Gong, Aizhen Jin', Jian-Min Yuan ${ }^{2,3}$, Eu Leong Yong \\ and Woon-Puay Koh ${ }^{4,5}$ \\ Department of Obstetrics and Gynaecology, Yong Loo Lin School of Medicine, National University of Singapore, \\ National University Health System, NUHS Tower Block, Level 12, 1E Kent Ridge Road, Singapore 119228, Singapore \\ ${ }^{1}$ National Registry of Diseases Office, Ministry of Health, Singapore 168937, Singapore \\ ${ }^{2}$ Division of Cancer Control and Population Sciences, University of Pittsburgh Cancer Institute, Pittsburgh, \\ Pennsylvania 15232, USA \\ ${ }^{3}$ Department of Epidemiology, University of Pittsburgh Graduate School of Public Health, Pittsburgh, \\ Pennsylvania 15232, USA \\ ${ }^{4}$ Duke-NUS Graduate Medical School Singapore, 8 College Road, Singapore 169857, Singapore \\ ${ }^{5}$ Saw Swee Hock School of Public Health, National University of Singapore, Singapore 117597, Singapore
}

Correspondence should be addressed to W-P Koh or E L Yong Emails woonpuay.koh@ duke-nus.edu.sg or obgyel@nus.edu.sg

\begin{abstract}
The estrogen levels of Asian women are different from those of Western women, and this could affect estrogen receptor (ER) bioactivity and breast cancer risk. We conducted a case-control study in 169 postmenopausal breast cancer cases and 426 matched controls nested within a population-based prospective cohort study, the Singapore Chinese Health Study, to evaluate the serum levels of estrogens and their receptor (ER $\alpha$ and ER $\beta$ )-mediated estrogenic activities in relation to breast cancer risk. Breast cancer cases had higher levels of estrogens and ER-mediated bioactivities in baseline serum than the controls. Compared with those in the lowest quartile, women in the highest quartile for estrone $\left(E_{1}\right)$ or ER $\alpha$-mediated bioactivity had increased breast cancer risk. After additional adjustment for $E R \beta$ bioactivity, free estradiol, and $E_{1}$ levels, serum ER $\alpha$-mediated bioactivity remained associated with increased breast cancer risk. Compared with those in the lowest quartile, women in the highest quartile for ER $\alpha$-mediated bioactivity had an odds ratio of 2.39 $(95 \% \mathrm{Cl}=1.17-4.88 ; P$ for trend $=0.016)$. Conversely, the positive association between $\mathrm{E}_{1}$ and cancer risk became null after adjustment for ER $\alpha$-mediated bioactivity, suggesting that the effect of $E_{1}$ could be mediated through ER $\alpha$. Factor(s) contributing to increased $\mathrm{ER} \alpha$-mediated estrogenic bioactivity in serum and its role as a predictor for breast cancer risk need to be validated in future studies.
\end{abstract}

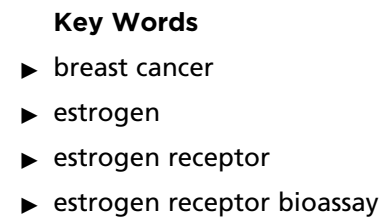

Endocrine-Related Cancer (2014) 21, 263-273

\section{Introduction}

There is ample experimental, epidemiological, and clinical evidence linking estrogens and breast cancer risk (Henderson \& Feigelson 2000, Russo \& Russo 2006). Several established risk factors for breast cancer are strongly associated with sex hormone levels, suggesting that these factors affect estrogen signaling pathways to impact breast cancer risk (Key et al. 2011). Endogenous hormone levels have been used to estimate breast cancer 
risk in nine previous prospective studies carried out in postmenopausal women (Key et al. 2002). An analysis of pooled data from these studies indicated that postmenopausal women with relatively high serum levels of sex hormones such as estradiol $\left(\mathrm{E}_{2}\right)$ and testosterone had a roughly twofold higher risk of breast cancer compared with those with lower levels. Of these studies, all, but one in Japan (Kabuto et al. 2000), were conducted in North America or Europe where women are known to have a higher BMI compared with their leaner Asian counterparts and also more likely to use hormone replacement therapy. Obesity could contribute to higher estrogen levels, as adipose tissues are a source of estrogens in postmenopausal women (Siiteri 1987). Furthermore, marked differences in circulating estrogen levels have been reported between Asian and Caucasian women (Bernstein et al. 1990, Shimizu et al. 1990, Wu \& Pike 1995).

Estrogen receptor $\alpha(E R \alpha)$ and $\operatorname{ER} \beta$ bioassays are classically used to identify estrogenic compounds present in the environment or to detect persistent organic pollutants in the serum of humans (Hjelmborg et al. 2006, Kanno et al. 2007, Kruger et al. 2008, Djiogue et al. 2010, Du et al. 2010). Recently, using the $\mathrm{ER} \alpha$ assay, it has been demonstrated that ER $\alpha$-mediated bioactivity in serum can predict hip fracture risk in menopausal women (Lim et al. 2012). The strength of such ER bioassays is that the overall effects of all factors (known and unknown) on ER activation can be quantified. Therefore, these ER bioassays measure the summated activity of all agonists and antagonists that either activate or inhibit the ERs.

In terms of breast cancer, the bioactivities of both ER $\alpha$ and ER $\beta$ have been shown to be independently associated with increased risk in European studies (Widschwendter et al. 2009, Fourkala et al. 2012). Specifically, in a casecontrol study conducted in Germany, women in the highest quintile of both serum $\operatorname{ER} \alpha$ and $\operatorname{ER} \beta$ bioactivities had approximately seven times higher breast cancer risk compared with those in the lower quintile (Widschwendter et al. 2009). More recently, in a casecontrol study nested in a cohort study of women in the $\mathrm{UK}, \mathrm{ER} \alpha$ bioactivity has been shown to be independently associated with breast cancer risk using serum collected more than 2 years before diagnosis for breast cancer cases (Fourkala et al. 2012). These studies suggest that assays for serum ER $\alpha$ and ER $\beta$ bioactivities may be useful for the prediction and management of breast cancer at a population level as well as in a clinical setting.

Singapore Chinese women are currently experiencing one of the highest rates of increase in breast cancer incidence globally. Over the past 35 years from 1970 to 2005 , the incidence of breast cancer in Singapore has tripled from 20.0 to 60.0/100 000 (National Registry of Diseases Office 2008). Factors causing the rapid increase in this historically low-risk population are largely unclear. Utilizing prospectively collected questionnaire data and serum collected from women of a population-based cohort study in Singapore, in the present study, we investigated the associations between estrogen and ER-mediated bioactivity levels and breast cancer risk among postmenopausal women in an Asian country. We provide evidence to suggest that factors other than estrone $\left(\mathrm{E}_{1}\right)$ and $\mathrm{E}_{2}$ may activate $E R \alpha$-mediated signaling pathways to increase breast cancer risk.

\section{Subjects and methods}

\section{Study population}

Both cases and controls were participants of the Singapore Chinese Health Study, a population-based prospective cohort study carried out in 63257 Chinese subjects (including 35298 women) who were aged 45-74 years during recruitment between April 1993 and December 1998 (Hankin et al. 2001). All the participants of this cohort study were residents of government-subsidized housing schemes, in which the majority $(86 \%)$ of Singaporeans resided at the time of recruitment. Study subjects were restricted to the two major Chinese dialect groups: Hokkien and Cantonese, who originated from two contiguous prefectures in southern China. The Institutional Review Board of the National University of Singapore approved this study.

During recruitment, the subjects were interviewed in-person using a structured questionnaire to collect information on tobacco use and medical history as well as a dietary component to assess current intake patterns. In addition, information on menstrual (including menopausal status) and reproductive (including menopausal hormone therapy use) histories was collected from the women. Between April 1994 and December 1999, blood and single-void urine specimens were collected from a random 3\% sample of study enrollees. Details of biospecimen collection, processing, and storage procedures have been described previously (Koh et al. 2003). Between January 2000 and April 2005, we extended our biospecimen collection to all surviving cohort members and collected biospecimens (blood/buccal cells and urine) from 32575 participants, representing a consent rate of about $60 \%$ of surviving cohort participants at that time.

Published by Bioscientifica Ltd. 
Among the 35298 women in this cohort, 15415 (44\%) donated blood for research. Only postmenopausal women without a history of breast cancer during recruitment were included in the present study.

\section{Case ascertainment}

Incident breast cancer cases were identified through the population-based cancer registry in Singapore (National Registry of Diseases Office 2008). All cases were further verified by manual checking of pathological and medical records. As of 28 June 2010, among 25584 women who were postmenopausal during recruitment, 573 had developed breast cancer. Among them, 169 women with breast cancer had donated blood before cancer diagnosis and were included as cases in this study. Compared with the other breast cancer patients who did not donate a blood sample, cases in this study were younger at diagnosis (66.7 vs 64.9 years). Patients who did not donate blood samples were less educated $(45.3 \%$ had no formal education) than those who did $(20.7 \%$ had no formal education). Those who did not donate biospecimens were also more likely to have advanced stage of breast cancer, but less likely to use hormone replacement therapy compared with those who donated. Otherwise, there was no significant difference in BMI or prevalence of positive family history for breast cancer between the two groups of breast cancer patients.

\section{Control selection}

For each of the 169 cases, up to three control subjects were randomly selected among all the female cohort participants who had donated blood samples and who were alive and free of breast cancer at the time of cancer diagnosis of their index case. The chosen controls were matched to the index case on age at study enrollment ( \pm 3 years), dialect group (Hokkien and Cantonese), and dates of study enrollment ( \pm 2 years) and of blood collection ( \pm 6 months). Among the 169 cases, there were 19 cases having only one eligible control each and 43 cases having only two controls each. The other 107 cases had three controls each.

\section{Blood analysis}

Serum samples of a given matched set (containing the samples from the case and one to three matched controls) were arranged in a random order, identified only by unique codes, and tested in the same laboratory batch for all measurements. Laboratory personnel were blinded to case or control status of the samples. Serum samples were thawed at $4{ }^{\circ} \mathrm{C}$ and individually filtered via $0.22 \mu \mathrm{m}$ sterile cartridges. Filtered sera were collected in aliquots for measurements of $\mathrm{E}_{1}, \mathrm{E}_{2}$, sex hormone-binding globulin (SHBG), and $E R \alpha$ - and ER $\beta$-mediated bioactivity levels.

Serum $\mathrm{E}_{1}$ and $\mathrm{E}_{2}$ levels were measured with liquid chromatography-tandem mass spectrometry (LC-MS/MS) using $\mathrm{d}_{4}-\mathrm{E}_{1}$ and $\mathrm{d}_{5}-\mathrm{E}_{2}$ as internal standards, as reported previously (Nelson et al. 2004). The respective intra-assay and inter-assay variability (coefficient of variation (\%)) ranges for $\mathrm{E}_{2}$ were $3.9-14.5 \%($ mean $=8.7 \%)$ and 1.2 $13.3 \%$ (mean $=6.3 \%)$ under the condition of $10-1000 \mathrm{pM}$ $\mathrm{E}_{2}$ respectively. The corresponding values for $\mathrm{E}_{1}$ were $1.3-15.7 \%($ mean $=8.2 \%)$ and $1.7-11.5 \%($ mean $=5.4 \%)$ under the condition of 25-1000 $\mathrm{pM} \mathrm{E} \mathrm{E}_{1}$.

Serum SHBG levels were quantified with a solid-phase, two-site chemiluminescent immunoassay using the Immulite Analyzer (Siemens Medical Solutions USA Inc., Malvern, PA, USA). The solid phase was a polystyrene bead with a MAB specific for SHBG. The intra-assay and inter-assay relative standard deviation (RSD) values for SHBG in the range of $2-18 \mathrm{nM}$ were 6.7 and $2.0 \%$ respectively. The percent of free $E_{2}$ was calculated from serum SHBG levels based on the following regression model: percent of free $E_{2}=-0.01533 \times$ serum $S H B G+2.921$ (Langley et al. 1985). Free $\mathrm{E}_{2}$ level for each subject was then computed as the product of percent of free $E_{2}$ and total $\mathrm{E}_{2}$ levels.

The biological activity of estrogens in serum was assessed using a validated estrogen-driven recombinant cell bioassay (Wong et al. 2007, Li et al. 2009). Human uterine cervical HeLa cells (ATCC, Manassas, VA, USA) were transformed to stably express either ER $\alpha$ (ESR1) or ER $\beta$ (ESR2). When exposed to test sera, luciferase activity expressed from these transformed HeLa cells reflects estrogenic bioactivity through four tandem copies of a consensus estrogen response element coupled to a luciferase gene stably incorporated into the genome. Such luciferase activity reflects the summated bioactivity of estrogenic ligands in serum. The expression levels of $\mathrm{ER} \alpha$ or ER $\beta$ in these recombinant cell lines were confirmed with immunoblotting. Strong expressions of ER $\alpha$ or ER $\beta$ protein were detected in the ER $\alpha$ or ER $\beta$ cell lines respectively (Fig. 1A). HeLa cells do not express ER $\alpha$, and the ER $\beta$-stable cell line does not contain any detectable ER $\alpha$ protein. HeLa cells do express low levels of ER $\beta$, and the ER $\alpha$-stable cell line reflects this, although the predominant receptor is ER $\alpha$. In the presence of the natural ligands $E_{1}$ and $E_{2}$, the $E R \alpha$ and $E R \beta$ cell lines exhibit dose-dependent bioactivity (Fig. 1B).

Published by Bioscientifica Ltd. 
A

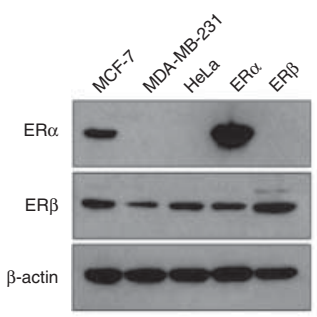

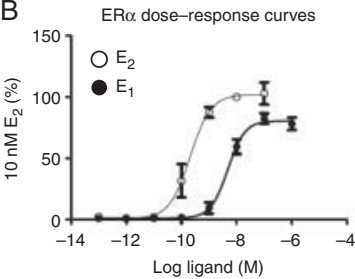

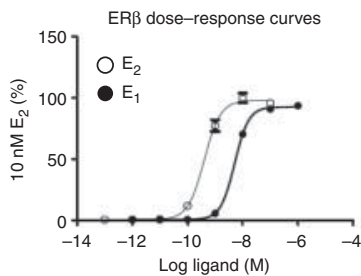

C
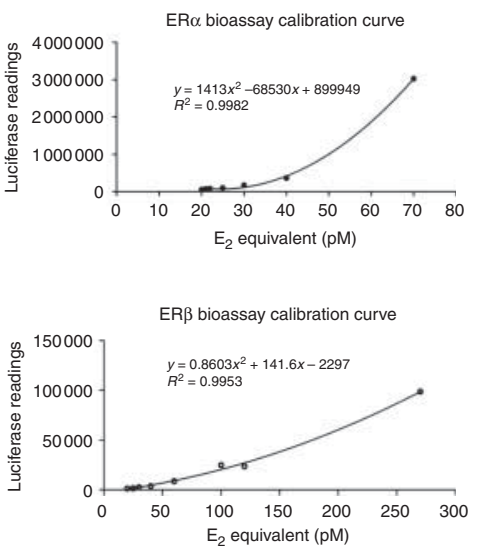

\section{Figure 1}

Estrogen receptor (ER) bioassay. (A) Immunoblot of ER $\alpha$ and $E R \beta$ proteins in stably transfected HeLa cells. Total cellular proteins were extracted from $E R \alpha$ or ER $\beta$ stably transfected HeLa cells, and the presence of ER $\alpha$ and ER $\beta$ proteins was detected with specific MABs. MCF-7 and MDA-MB-231 cell lysates were used as positive and negative controls for $E R \alpha$ respectively. HeLa cells are original cells without any transfection of ER $\alpha$ or ER $\beta$.

Recombinant cells were passaged, plated in a 96-well plate in 10\% charcoal-treated (CT) fetal bovine serum (FBS), and allowed to adhere overnight. Culture medium was then removed and replaced with incremental amounts of $E_{2}$ in $10 \%$ male human serum (Sigma) stripped of steroids using charcoal treatment for calibration standards. Stock solutions of $\mathrm{E}_{2}$ were prepared in serum and diluted to $10 \%$ using culture medium (Eagle's Minimum Essential Medium), and duplicates of each concentration were included in the plate. Similarly, test serum was also diluted to $10 \%$ using culture medium and added to the cells in duplicates. Baseline level of $\mathrm{E}_{2}$ in CT human serum is about $20 \mathrm{pM}$ tested using LC-MS/MS. After an incubation period of $24 \mathrm{~h}$, the medium was decanted, and the cells were washed with PBS and lysed with the Mammalian Protein Extraction Reagent (MPER) obtained from Thermo Scientific (Rockford, IL, USA). Luciferase activity was measured using the Luciferase Assay System (Promega) on the Glomax 96-well Microplate Luminometer (Promega).

All test sera were tested on the same day using the same batch of cells. Calibration standards and quality control (QC) samples were included in every 96-well plate. Readings from the plate were used if QC samples in that plate had relative errors $<30 \%$. If the relative error was $>30 \%$, the assay was repeated. The mean (s.D.) of relative errors for $\mathrm{ER} \alpha$ bioassay was $5.85 \%$ (5.16) and for $\operatorname{ER} \beta$ bioassay was $11.51 \%(7.87)$.
(B) Dose-dependent activation of luciferase reporter gene in $E R \alpha$ and ER $\beta$ cells by estradiol $\left(E_{2}\right)$ and estrone $\left(E_{1}\right)$. Medium with $10 \%$ CT FBS was spiked with $E_{2}$ and $E_{1}$. Readings are expressed as the percent of highest activation of $E_{2}$ at $10 \mathrm{nM}$. (C) Representative calibration curves of ER-driven reporter gene bioassays for the quantification of ER-mediated bioactivity of serum samples.

Calibration curves were fitted with a regression model that visually best fits the points within the range of the test samples and maximizes the correlation coefficient $\left(R^{2}\right)$ value. The $R^{2}$ values for ER $\alpha$ and $\mathrm{ER} \beta$ ranged from 0.96 to 0.99 . Total estrogen-mediated activity was calculated based on the average luminescence readings for each test serum, and it is expressed as pM $\mathrm{E}_{2}$ equivalent obtained by interpolation from calibration curves in each plate. Microsoft Excel Software was used for curve fitting and interpolation. For the $\mathrm{ER} \alpha$ bioassay, the calibration curve ranged from 5 to $70 \mathrm{pM}$, with intra-assay and interassay RSD values of 6 and 14\% respectively (Fig. 1C, upper panel). For the ER $\beta$ bioassay, the calibration curve ranged from 5 to $250 \mathrm{pM}$, and the intra-assay and inter-assay RSD values were 8.1 and $16 \%$ respectively (Fig. 1C, lower panel). Five serum samples had ER $\beta$ values below the detection limit and were thus omitted from the analysis.

\section{Statistical analysis}

The distributions of all biomarkers measured were markedly skewed with a long tail toward high values, which were corrected, to a large extent, by transforming the original values to logarithmic values. Therefore, a formal statistical test was carried out on logarithmically transformed values and geometric (as opposed to arithmetic) means were obtained. The analysis of covariance (ANCOVA) method was used to examine the differences in

Published by Bioscientifica Ltd 
Table 1 Baseline characteristics of breast cancer cases and controls (mean (s.D.) or number (\%)), the Singapore Chinese Health Study

\begin{tabular}{|c|c|c|}
\hline & Cases $(n=169)$ & Controls $(n=426)$ \\
\hline $\begin{array}{l}\text { Mean age at blood draw } \\
\text { (years) }\end{array}$ & $60.9(7.2)$ & $60.0(6.5)$ \\
\hline \multicolumn{3}{|l|}{ BMI $\left(\mathrm{kg} / \mathrm{m}^{2}\right)$} \\
\hline$<20$ & $16(9.5)$ & $45(10.6)$ \\
\hline $20-24$ & $86(50.9)$ & $246(57.8)$ \\
\hline $24-28$ & $50(29.6)$ & $109(25.6)$ \\
\hline $28+$ & $17(10.1)$ & $26(6.1)$ \\
\hline \multicolumn{3}{|l|}{ Dialect (\%) } \\
\hline Cantonese & $96(56.8)$ & $249(58.5)$ \\
\hline Hokkien & $73(43.2)$ & $177(41.5)$ \\
\hline \multicolumn{3}{|l|}{ Level of education (\%) } \\
\hline No formal education & $35(20.7)$ & $109(25.6)$ \\
\hline Primary school & $81(47.9)$ & $195(45.8)$ \\
\hline Secondary and above & $53(31.4)$ & $122(28.6)$ \\
\hline \multicolumn{3}{|l|}{ Age at menarche (years) } \\
\hline$<13$ & $27(16.0)$ & $82(19.3)$ \\
\hline $13-14$ & $77(45.6)$ & $164(38.5)$ \\
\hline $15-16$ & $52(30.8)$ & 139 (32.6) \\
\hline $17+$ & $13(7.6)$ & $41(9.6)$ \\
\hline \multicolumn{3}{|l|}{ Number of live births } \\
\hline None & $20(11.8)$ & $32(7.5)$ \\
\hline $1-2$ & $61(36.1)$ & $134(31.5)$ \\
\hline $3-4$ & $54(31.9)$ & $184(43.2)$ \\
\hline $5+$ & $34(20.1)$ & $76(17.8)$ \\
\hline $\begin{array}{l}\text { Use of menopausal } \\
\text { hormone therapy (\%) }\end{array}$ & $18(10.7)$ & $26(6.1)$ \\
\hline $\begin{array}{l}\text { Family history of breast } \\
\text { cancer }\end{array}$ & $4(2.4)$ & $5(1.2)$ \\
\hline
\end{tabular}

the levels of serum biomarkers between breast cancer cases and control subjects with adjustment for other covariates, namely BMI $\left(<20,20-<24,24-<28\right.$, and $\left.28+\mathrm{kg} / \mathrm{m}^{2}\right)$, number of live births (none, one to two, three to four, and five or more), age at menarche $(<13,13-14,15-16$, and $17+$ years), use of hormone replacement (yes, no) and family history of breast cancer (yes, no). We also included set number as a covariate to account for the matched case-control design in this study.

We used the conditional logistic regression method to examine the associations between serum biomarkers measured and breast cancer risk in our main analysis. For subanalysis involving stratification by receptor positivity of breast cancer cases and time between blood draw and diagnosis, unconditional logistic regression models that included all the controls in this study were used to examine the association between serum biomarkers and breast cancer risk. In this study, our aim was to determine how estrogen and bioactivity levels in cases compared with those in the controls might affect breast cancer risk. Hence, study subjects were grouped into quartiles of individual serum parameters based on their distributions among control subjects because they formed the baseline or comparison group. Furthermore, in the general population, as the number of women without breast cancer far exceeds that of those with breast cancer, the levels in a population are essentially defined by the levels in the controls. The magnitude of the association was assessed by odds ratio (OR) and its corresponding 95\% CI and $P$ value. An additional analysis also included quartile levels of $E_{1}$, free $E_{2}, S H B G$, and $E R \alpha$ - and ER $\beta$-mediated bioactivities in the same model. For the unconditional logistic regression analyses, age at blood draw was included as a covariate. All the analyses were carried out using the SAS, version 9.1 (SAS Institute, Inc., Cary, NC, USA). All $P$ values reported are two sided. The statistical significance level was set at a two-sided $P$ value of 0.05 .

\section{Results}

For the 169 breast cancer cases, the mean time interval from blood draw to breast cancer diagnosis was 4.0 years (s.D. 2.5 years), and only 43 cases (25\%) had blood drawn within 2 years of cancer diagnosis. The mean age at cancer diagnosis was 64.9 (s.D. 7.5; range 48.3-82.0) years. Compared with the controls, a higher proportion of women with breast cancer had BMI $\geq 24 \mathrm{~kg} / \mathrm{m}^{2}$, had secondary school education or higher, were nulliparous or had fewer live births, and were older at the first live

Table 2 Geometric means $(95 \% \mathrm{Cl})$ of serum biomarkers in postmenopausal breast cancer cases and controls, the Singapore Chinese Health Study

\begin{tabular}{|c|c|c|c|}
\hline & Cases $(n=169)$ & Controls $(n=426)$ & Two-sided $P^{a}$ \\
\hline Estrone (pM) & $404.70(355-461.36)$ & $335.96(308.28-366.12)$ & 0.02 \\
\hline Estradiol ( $\left.E_{2} ; p M\right)$ & $66.26(57.26-76.66)$ & $58.82(53.46-64.74)$ & 0.19 \\
\hline SHBG (nM) & $44.60(41.32-48.16)$ & $47.62(45.3-50.08)$ & 0.16 \\
\hline Free $E_{2}(p M)$ & $1.38(1.2-1.6)$ & $1.16(1.06-1.28)$ & 0.05 \\
\hline$E R \alpha$ activity (pM $E_{2}$ equivalent) & $25.54(24.66-26.44)$ & $24.40(23.84-24.96)$ & 0.03 \\
\hline ER $\beta$ activity ( $p M E_{2}$ equivalent) & $25.22(24.24-26.24)$ & $24.22(23.6-24.86)$ & 0.10 \\
\hline
\end{tabular}

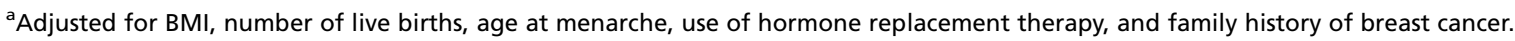

http://erc.endocrinology-journals.org DOI: $10.1530 /$ ERC-13-0233
(C) 2014 Society for Endocrinology Printed in Great Britain
Published by Bioscientifica Ltd. 
birth, which were observations similar to previous results published for this cohort of women (Koh et al. 2003). Only $6.1 \%$ among the controls and $10.7 \%$ among the cases used hormone replacement therapy (Table 1).

Breast cancer cases tended to have increased circulating serum $E_{1}, E_{2}$, free $E_{2}$, and $E R \alpha$ - and $E R \beta$-mediated bioactivity levels, but lower serum SHBG levels than the controls, although only the differences for $E_{1}$, free $E_{2}$, and ER $\alpha$-mediated bioactivity levels reached statistical significance (Table 2). After adjusting for BMI, number of live births, age at menarche, use of hormone replacement, and family history of breast cancer, borderline dosedependent activity was observed for $\mathrm{E}_{1}$, which exhibited an association with a $60 \%$ increase in risk for women in the highest quartile relative to those in quartile 1 (OR, 1.60; 95\% CI, 0.94-2.72; $P$ for trend $=0.05$; Table 3). There were no clear dose-dependent associations between serum total $\mathrm{E}_{2}$, free $\mathrm{E}_{2}$, SHBG, and $\mathrm{ER} \beta$-mediated activity levels and breast cancer risk. Strikingly, compared with that in women in the lowest quartile, ER $\alpha$-mediated bioactivity was associated with a dose-dependent increase in breast cancer risk, ranging from a $45 \%$ higher risk in women in quartile 2 to a $159 \%$ higher risk in those in the highest quartile (OR, 2.59; 95\% CI, 1.44-4.65; $P$ for trend $=0.001$; Table 3 ). Reanalysis done with a minimal value $(20 \mathrm{pM})$ assigned to five values of ER $\beta$ below the limit of detection yielded essentially the same results; there was no significant association between serum ER $\beta$

Table 3 Association between serum estrogenic parameters and postmenopausal breast cancer risk, the Singapore Chinese Health Study

\begin{tabular}{|c|c|c|c|c|}
\hline Biomarker & Range & Cases & Controls & Model 1 OR $(95 \% \mathrm{Cl})$ \\
\hline \multicolumn{5}{|l|}{ Estrone } \\
\hline Q1 & $23.65-205.5$ & 37 & 106 & 1.00 \\
\hline Q2 & $207.5-284.0$ & 33 & 106 & $0.86(0.49-1.51)$ \\
\hline Q3 & $285.5-455.5$ & 39 & 107 & $1.02(0.59-1.75)$ \\
\hline Q4 & $\geq 457.5$ & 60 & 105 & $1.63(0.97-2.73)$ \\
\hline$P$ for trend & & & & 0.04 \\
\hline \multicolumn{5}{|l|}{ Estradiol } \\
\hline Q1 & $4.365-34.3$ & 33 & 106 & 1.00 \\
\hline Q2 & $34.4-50.25$ & 42 & 107 & $1.21(0.69-2.14)$ \\
\hline Q3 & $50.35-76.6$ & 47 & 105 & $1.42(0.80-2.50)$ \\
\hline Q4 & $\geq 76.95$ & 47 & 106 & $1.40(0.80-2.46)$ \\
\hline$P$ for trend & & & & 0.21 \\
\hline \multicolumn{5}{|l|}{ SHBG } \\
\hline Q1 & $8.39-33.5$ & 55 & 106 & 1.00 \\
\hline Q2 & $33.7-47.4$ & 34 & 106 & $0.62(0.37-1.05)$ \\
\hline Q3 & $47.5-67.53$ & 46 & 106 & $0.81(0.49-1.33)$ \\
\hline Q4 & $\geq 68.1$ & 34 & 106 & $0.61(0.36-1.04)$ \\
\hline$P$ for trend & & & & 0.16 \\
\hline \multicolumn{5}{|l|}{ Free estradiol } \\
\hline Q1 & $0.065-0.668$ & 30 & 106 & 1.00 \\
\hline Q2 & $0.673-1.04$ & 42 & 106 & $1.33(0.75-2.37)$ \\
\hline Q3 & $1.045-1.661$ & 51 & 106 & $1.71(0.97-3.00)$ \\
\hline Q4 & $\geq 1.666$ & 46 & 106 & $1.56(0.88-2.76)$ \\
\hline$P$ for trend & & & & 0.09 \\
\hline \multicolumn{5}{|l|}{ ER $\alpha$ activity } \\
\hline Q1 & $12.39-21.01$ & 26 & 107 & 1.00 \\
\hline Q2 & $21.03-23.63$ & 38 & 106 & $1.47(0.81-2.66)$ \\
\hline Q3 & $23.66-26.64$ & 41 & 106 & $1.64(0.91-2.96)$ \\
\hline Q4 & $\geq 26.65$ & 64 & 106 & $2.80(1.58-4.97)$ \\
\hline$P$ for trend & & & & 0.0004 \\
\hline \multicolumn{5}{|l|}{ ER $\beta$ activity } \\
\hline Q1 & $11.03-20.16$ & 37 & 104 & 1.00 \\
\hline Q2 & $20.22-24.46$ & 40 & 104 & $1.07(0.59-1.91)$ \\
\hline Q3 & $24.47-27.48$ & 33 & 104 & $0.96(0.48-1.94)$ \\
\hline Q4 & $\geq 27.51$ & 54 & 104 & $1.74(0.89-3.41)$ \\
\hline$P$ for trend & & & & 0.08 \\
\hline
\end{tabular}

\section{Model 2 OR (95\% Cl)}

Model 2 OR (95\% CI)

1.00
$0.87(0.49-1.54)$
$1.10(0.63-1.92)$
$1.60(0.94-2.72)$
0.05
1.00
$1.15(0.64-2.06)$
$1.43(0.80-2.54)$
$1.33(0.75-2.36)$
0.26
1.00

$0.65(0.38-1.11)$

$0.80(0.47-1.34)$

$0.65(0.37-1.12)$

0.20

1.00

$1.29(0.73-2.30)$

$1.72(0.97-3.03)$

$1.47(0.83-2.61)$

0.13

1.00

$1.45(0.79-2.64)$

$1.60(0.88-2.92)$

2.59 (1.44-4.65)

0.001

1.00

$1.01(0.56-1.84)$

$0.96(0.47-1.95)$

$1.53(0.77-3.04)$

0.19
Model 3 OR (95\% Cl)

1.00

$0.83(0.45-1.51)$

$0.90(0.49-1.66)$

$1.32(0.63-2.75)$

0.54

1.00

$1.01(0.54-1.89)$

$1.17(0.61-2.26)$

$0.78(0.37-1.66)$ 0.60

1.00

$0.72(0.41-1.24)$

$0.94(0.55-1.61)$

$0.74(0.41-1.34)$ 0.52

1.00

$1.07(0.58-1.96)$

$1.37(0.74-2.54)$

$0.78(0.37-1.63)$

0.77

1.00

$1.30(0.69-2.45)$

$1.44(0.74-2.81)$

$2.39(1.17-4.88)$ 0.016

1.00

$0.99(0.54-1.82)$

$0.94(0.46-1.94)$

$1.41(0.69-2.88)$ 0.31

Model 1, unadjusted model; Model 2, adjusted for BMI $\left(<20,20-<24,24-<28\right.$, and $28+\mathrm{kg} / \mathrm{m}^{2}$ ), number of live births (none, one to two, three to four, and five or more), age at menarche ( $<13,13-14,15-16$, and 17+ years), use of hormone replacement therapy (yes, no), and family history of breast cancer (yes, no); Model 3, adjusted for covariates in Model 1 and also quartile values of serum estrone, free estradiol or total estradiol (for SHBG), SHBG, ER $\alpha$ activity, and ER $\beta$ activity; OR, odds ratio.

http://erc.endocrinology-journals.org DOI: 10.1530/ERC-13-0233
(C) 2014 Society for Endocrinology Printed in Great Britain
Published by Bioscientifica Ltd 
Table 4 Association between serum ER $\alpha$-mediated bioactivity and postmenopausal breast cancer risk according to ER status of cancer cases, the Singapore Chinese Health Study

\begin{tabular}{|c|c|c|c|}
\hline Biomarker & Cases & Controls & OR $(95 \% \mathrm{Cl}) *$ \\
\hline \multicolumn{4}{|l|}{$\begin{array}{l}\text { ER-positive } \\
\text { cancer }\end{array}$} \\
\hline \multicolumn{4}{|l|}{ ER $\alpha$ activity } \\
\hline Q1 & 11 & 107 & 1.00 \\
\hline Q2 & 17 & 106 & $1.46(0.63-3.35)$ \\
\hline Q3 & 13 & 106 & $0.95(0.39-2.34)$ \\
\hline Q4 & 28 & 106 & $2.43(1.00-5.94)$ \\
\hline$P$ for trend & & & 0.10 \\
\hline \multicolumn{4}{|l|}{$\begin{array}{l}\text { ER-negative } \\
\text { cancer }\end{array}$} \\
\hline \multicolumn{4}{|l|}{ ER $\alpha$ activity } \\
\hline Q1 & 5 & 107 & 1.00 \\
\hline Q2 & 7 & 106 & $2.28(0.66-7.88)$ \\
\hline Q3 & 9 & 106 & $3.26(0.97-10.95)$ \\
\hline Q4 & 9 & 106 & $3.63(1.01-13.08)$ \\
\hline$P$ for trend & & & 0.04 \\
\hline \multicolumn{4}{|l|}{$\begin{array}{l}\text { ER unknown } \\
\text { cancer }\end{array}$} \\
\hline \multicolumn{4}{|l|}{$\mathrm{ER} \alpha$ activity } \\
\hline Q1 & 10 & 107 & 1.00 \\
\hline Q2 & 14 & 106 & $1.27(0.53-3.07)$ \\
\hline Q3 & 19 & 106 & $1.56(0.66-3.70)$ \\
\hline Q4 & 27 & 106 & $1.71(0.70-4.20)$ \\
\hline$P$ for trend & & & 0.21 \\
\hline
\end{tabular}

*Adjusted for BMI $\left(<20,20-<24,24-<28\right.$, and $\left.28+\mathrm{kg} / \mathrm{m}^{2}\right)$, number of live births (none, one to two, three to four, and five or more), age at menarche $(<13,13-14,15-16$, and $17+$ years), use of hormone replacement therapy (yes, no), family history of breast cancer (yes, no), and quartile value of estrone and free estradiol levels. OR, odds ratio.

levels and breast cancer risk. To examine the independent effect of individual estrogenic factors measured on breast cancer risk, further adjustment for $E_{1}$, free $E_{2}$, SHBG, and $E R \alpha$ - and ER $\beta$-mediated bioactivity levels was done (Table 3, last column). After adjusting for ER $\alpha$-mediated activity, the dose-dependent relationship between $\mathrm{E}_{1}$ and breast cancer risk was no longer evident; the ORs (95\% CI) for those in quartiles 2,3 , and 4 were $0.80(0.45-1.42), 0.88$ $(0.49-1.57)$, and $1.08(0.58-1.99)$ respectively ( $P$ for trend $=0.74)$, suggesting that $E R \alpha$-mediated bioactivity was primarily responsible for the effect of $E_{1}$ on breast cancer risk. Additional adjustment for free $\mathrm{E}_{2}$, SHBG, and ER $\beta$ bioactivity levels did not materially change the risk estimates (Table 3). By contrast, even after adjusting for $E_{1}$, free $E_{2}$, SHBG, and ER $\beta$ bioactivity levels, the strong association with $\mathrm{ER} \alpha$-mediated activity was essentially unaltered with a 2.4-fold increase (OR, 2.39; 95\% CI, 1.174.88; $P=0.016$ ) in breast cancer risk (Table 3). To further delineate the role of serum ER $\alpha$ bioactivity, we also carried out an analysis to compare risk in ER $\alpha$-positive or $E R \alpha$ negative tumor cases. Data on ER status were available for
$58.6 \%$ of the breast cancer cases. There were $69 \mathrm{ER} \alpha$ positive and $30 \mathrm{ER} \alpha$-negative breast cancer diagnoses. The results suggested that the positive association between ER $\alpha$-mediated activity and breast cancer risk was present in both subtypes of breast cancer. Compared with those of women in the lowest quartile, the ORs (95\% CI) of women in the highest quartile were statistically significant at 2.43 (1.00-5.94) for ER-positive breast cancer and 3.63 (1.01-13.08) for ER-negative breast cancer (Table 4).

Finally, we examined the association between ER $\alpha$ mediated activity and breast cancer risk by time between blood draw to cancer diagnosis. Risk estimates obtained from the analysis of cases with blood drawn within 2 years of cancer diagnosis were essentially similar to those obtained from the analysis of cases with blood drawn more than 2 years before cancer diagnosis. Although the $P$ for trend was of borderline statistical significance $(P=0.08)$ for the analysis limited to cases with blood drawn more than 2 years before cancer diagnosis, relative to those in the lowest quartile, women in the highest quartile in this group still had significantly increased breast cancer risk (OR, 2.15; 95\% CI, 1.07-4.33; Table 5).

\section{Discussion}

This is the first study to investigate the effect of estrogens and ER $\alpha$ - and ER $\beta$-mediated bioactivities on the risk of breast cancer in Chinese postmenopausal women.

Table 5 Association between serum ER $\alpha$-mediated bioactivity and postmenopausal breast cancer risk according to time between blood draw and cancer diagnosis for cases, the Singapore Chinese Health Study

\begin{tabular}{|c|c|c|c|}
\hline Biomarker & Cases & Controls & OR $(95 \% \mathrm{CI})$ * \\
\hline \multicolumn{4}{|c|}{ Within 2 years of blood draw and cancer diagnosis } \\
\hline \multicolumn{4}{|c|}{ ER $\alpha$ activity } \\
\hline Q1 & 8 & 107 & 1.00 \\
\hline Q2 & 4 & 106 & $0.57(0.16-2.02)$ \\
\hline Q3 & 11 & 106 & $1.46(0.53-4.03)$ \\
\hline Q4 & 20 & 106 & $2.67(0.94-7.54)$ \\
\hline$P$ for trend & & & 0.02 \\
\hline
\end{tabular}

More than 2 years between blood draw and cancer diagnosis ER $\alpha$ activity

$\begin{array}{llll}\text { Q1 } & 18 & 107 & 1.00 \\ \text { Q2 } & 34 & 106 & 1.83(0.95-3.50) \\ \text { Q3 } & 30 & 106 & 1.48(0.75-2.91) \\ \text { Q4 } & 44 & 106 & 2.15(1.07-4.33) \\ P \text { for trend } & & & 0.08\end{array}$

*Adjusted for BMI ( $<20,20-<24,24-<28$, and $\left.28+\mathrm{kg} / \mathrm{m}^{2}\right)$, number of live births (none, one to two, three to four, and five or more), age at menarche $(<13,13-14,15-16$, and $17+$ years $)$, use of hormone replacement therapy (yes, no), family history of breast cancer (yes, no), and quartile value of estrone and free estradiol levels. OR, odds ratio. http://erc.endocrinology-journals.org DOI: 10.1530/ERC-13-0233
(C) 2014 Society for Endocrinology Printed in Great Britain 
Our data demonstrated that higher levels of ER $\alpha$-mediated bioactivity in sera were associated with an increased risk of cancer and that estrogens, especially $\mathrm{E}_{1}$, influenced cancer risk via interaction with $\mathrm{ER} \alpha$ in the pathogenesis of postmenopausal breast cancer.

The geometric means of total free $E_{2}, E_{1}$, and $E R \alpha$ bioactivity levels were significantly higher in pre-disease serum collected from breast cancer cases than in that from controls. However, after dividing the biomarker levels into quartiles and assessing their association with breast cancer risk, a borderline dose-dependent relationship was also observed with the highest quartile of $\mathrm{E}_{1}$ exhibiting a $60 \%$ higher risk of breast cancer. Although high $\mathrm{E}_{2}$ levels are known to be associated with a higher risk of breast cancer in postmenopausal women (Kabuto et al. 2000, Key et al. 2003, Manjer et al. 2003, Missmer et al. 2004, ZeleniuchJacquotte et al. 2004, Kaaks et al. 2005, Eliassen et al. 2006, Baglietto et al. 2010, Farhat et al. 2011), the role of $\mathrm{E}_{1}$ in breast cancer carcinogenesis is less well appreciated. There is evidence that $E_{1}$ levels, but not $E_{2}$, can be higher depending on lifestyle factors. Japanese women born in the USA have mean $\mathrm{E}_{1}$ levels higher than those in Caucasian counterparts, contrasting with the largely similar mean $\mathrm{E}_{2}$ levels between these two populations (Probst-Hensch et al. 2000). In that study, differences in $\mathrm{E}_{1}$ levels were still evident after adjustment for age, weight, and androstenedione levels. On the other hand, Japanese women living in rural areas were found to have $43 \%$ lower $\mathrm{E}_{1}$ levels compared with weight- and age-matched Caucasian women living in California (Wu \& Pike 1995), suggesting that the transition from a rural to an urban lifestyle may have a contributory effect on high $\mathrm{E}_{1}$ levels. One lifestyle factor may be shift work, as women working graveyard shifts have been reported to have significantly higher $\mathrm{E}_{1}$ levels (20 vs $11.5 \mathrm{pg} / \mathrm{ml}$ ) compared with those who never worked night shifts (Nagata et al. 2008). Although $\mathrm{E}_{1}$ has $20-80 \%$ of the bioactivity of $\mathrm{E}_{2}$ depending on the assay used (Fang et al. 2000), its higher levels indicate that its contribution to overall estrogenicity and breast cancer risk is significant in the postmenopausal condition in our cohort. The challenge is to define the role of lifestyle modifications that may lower $\mathrm{E}_{1}$ levels and breast cancer risk. The loss of statistically significant association with $E_{1}$ levels in this study was primarily due to adjustment for $\mathrm{ER} \alpha$ activity, and we deduced that the effect of $\mathrm{E}_{1}$ in the pathogenesis of postmenopausal breast cancer could be mediated via its binding to ER $\alpha$.

Conversely, ER $\alpha$-mediated bioactivity appeared to be an independent risk factor for breast cancer risk. Logistic regression analyses indicated that even after adjustment for the known factors of estrogenic action such as $E_{2}, E_{1}$, and BMI, women whose $\mathrm{ER} \alpha$-mediated bioactivity was in the highest quartile still had significantly higher breast cancer risk compared with those in the lowest quartile, suggesting that other factor(s), besides $\mathrm{E}_{1}$ and $\mathrm{E}_{2}$, was acting via the $E R \alpha$-mediated genomic signaling systems to increase breast cancer risk. This dose-dependent increase in risk with high ER $\alpha$-mediated bioactivity was evident in periods before 4 years and within 2 years of blood draw, indicating the robustness of the association. To our knowledge, this is the first study to use mammalian cellbased bioassays to prospectively examine the relationship between $\mathrm{ER} \alpha$-mediated bioactivity and breast cancer risk. One recent UK study, utilizing a yeast-based reporter gene assay system, did not observe any overall relationship between cancer risk and receptor bioactivity. In this study (Fourkala et al. 2012), an association between ER $\alpha$ mediated bioactivity and breast cancer risk was only present in the subset of cases whose blood was collected more than 2 years before cancer diagnosis (Fourkala et al. 2012). This contradicted the findings of a case-control study that the same group of investigators had conducted in Germany using blood collected from cases after clinical diagnosis and showing a strong association between ER $\alpha$ bioactivity and cancer risk (Widschwendter et al. 2009). Differences between our study and the study carried out by the UK group could be due to the use of mammalian cells by us, which are more physiologically relevant to differentiate between agonists and antagonists compared with yeast cell-based bioassays used by other investigators (Widschwendter et al. 2009, Fourkala et al. 2012). In addition, the co-regulators involved in the transactivation of estrogen-sensitive reporter genes has been reported to differ between yeast and mammalian systems (Kohno et al. 1994).

Although the two most abundant estrogens present in the serum $\left(\mathrm{E}_{2}\right.$ and $\left.\mathrm{E}_{1}\right)$ can bind to $\mathrm{ER} \alpha$ and activate it, many other compounds in the serum are also known to be capable of activating the receptor. These include estrogen metabolites from birth control pills and endocrinedisrupting compounds (EDCs) that have estrogenic activity. A wide range of synthetic endocrine-disrupting chemicals such as dioxins and polychlorinated biphenyls, bisphenol A, and pesticides (endosulfan, toxaphene, and dieldrin) are estrogenic compounds that can exert biological effects at trace concentrations and have the potential to provoke additive estrogenic mixture effects at low doses, even at no observed effect levels (DiamantiKandarakis et al. 2009, Kandaraki et al. 2011). Thus, $\mathrm{ER} \alpha$-mediated bioactivity could be a more comprehensive

Published by Bioscientifica Ltd. 
measurement of the combined effects of all known and unknown estrogenic compounds present in the sera of women, all of which could affect breast cancer risk. Our data indicating that the risk due to increased $E R \alpha-$ mediated bioactivity was independent of endogenous estrogens support the hypothesis that environmental factors may have a contributory role in breast cancer risk in our cohort. More research is warranted to identify these EDCs. This is consistent with the rapid increase in breast cancer rates in rapidly modernizing Singapore.

While the UK study included only ER-positive cases (Fourkala et al. 2012), our study included both ER-positive and ER-negative breast cancer cases and showed that ER $\alpha$ mediated bioactivity was associated with increased risk for both subtypes of cancers, suggesting that ER-negative cancer also depends on estrogenic activity for growth. Intriguingly, risk was highest in patients with $\mathrm{ER} \alpha-$ negative tumors, increasing 15-fold within the highest quartile of ER $\alpha$ bioactivity, suggesting that compounds that were activating the $E R \alpha$ genomic signaling cascade were also capable of activating other estrogenic signaling pathways in breast cancer tissues with absent or significantly lower levels of $E R \alpha$. Reports from earlier studies showed that ovariectomy prevented the formation of both ER $\alpha$-positive and ER $\alpha$-negative breast cancers, thus suggesting that the estrogen-driven pathway could also play a role in the development of ER-negative breast cancer (Early Breast Cancer Trialists' Collaborative Group 1992). Hence, we hypothesize that our mammalian reporter gene assay has reflected the presence of estrogenic compounds present in the serum of ER $\alpha$-negative breast cancer patients that may activate estrogen signaling in the absence of intact ER $\alpha$. One example is membranebound $\mathrm{ER} \alpha$ 36, a truncated estrogen-sensitive receptor present in ER-negative breast cancer, which can mediate nongenomic estrogen signaling in the carcinogenesis of ER-negative tumors (Rao et al. 2011).

Although our data were suggestive of a 1.5-fold increase in the risk of breast cancer for women in the highest quartile, the association of breast cancer risk with ER $\beta$ bioactivity did not reach statistical significance and was weaker than that with ER $\alpha$ bioactivity. The role of ER $\beta$ in breast cancer has been controversial. Breast cancer patients who are treated with tamoxifen and have high expression levels of ER $\beta$ were found to have better response and longer survival time (Esslimani-Sahla et al. 2004, Hopp et al. 2004). On the other hand, in ER $\alpha$ negative breast cancer, high ER $\beta$ expression is positively correlated with poor prognostic phenotypes (Skliris et al. 2006). Some of these ligands with preferential binding to
ER $\beta$ have been shown to be associated with decreased breast cancer risk. For example, genistein is a soy phytoestrogen possessing high affinity for ER $\beta$ (Lee et al. 2004), and higher soy intake has been shown to be associated with a reduced risk of breast cancer (Iwasaki et al. 2008, Wu et al. 2008).

The strength of this study is the nesting of the study within a population-based prospective cohort study that allows the use of questionnaire data and blood specimens collected before the occurrence of breast cancer to reduce recall and reverse causality bias. Cancer cases were identified using a comprehensive nationwide cancer registry. The limitations of this study are that the results are based on blood samples collected at a single time point, as the natural fluctuation of biomarkers that most probably occurred equally in both cases and controls could lead to the underestimation of the true associations with breast cancer risk. In this cohort, among postmenopausal women who gave blood for research, we limited the selection of cases to women who donated blood before the occurrence of breast cancer. Differences in factors such as age and hormone replacement therapy use between breast cancer cases included and those excluded in this study were accounted for either by matching or by statistical adjustment in our analyses. Furthermore, willingness to donate blood for research did not influence the biomarker-breast cancer association in this study. In addition, we acknowledge that the presence of existing occult tumors could play a role in the association between ER $\alpha$-mediated bioactivity and breast cancer risk in this group of patients with an average follow-up period of 4 years. Finally, the relatively small sample size, especially in the stratification by ER positivity, does not give us sufficient power to detect significant differences in the levels of most of the blood parameters between cases and controls.

In conclusion, ER $\alpha$-mediated bioactivity in sera was independently associated with a significantly increased risk of postmenopausal breast cancer. The measurement of this serum biomarker in postmenopausal women may have the potential to be developed into a clinical index for the prediction of breast cancer risk or the monitoring of patients on chemopreventive therapy for breast cancer.

\section{Declaration of interest}

The authors declare that there is no conflict of interest that could be perceived as prejudicing the impartiality of the research reported.

Published by Bioscientifica Ltd. 


\section{Funding}

This study was funded by Singapore Cancer Society Cancer Research Grant (DRA Ref: 2010-09-083), Singapore National Medical Research Council (R-174-000-137-275), and National Institutes of Health, USA (NCI RO1 CA55069, R35 CA53890, R01 CA80205, and R01 CA144034).

\section{Author contribution statement}

W-P Koh and E L Yong conceived the study. V W Lim, J Li, Y Gong, and $E L$ Yong carried out the biomarker assays. A Jin, J-M Yuan, and W-P Koh carried out the statistical analysis. V W Lim, J-M Yuan, W-P Koh, and E L Yong drafted the manuscript. All authors edited and approved the final manuscript.

\section{Acknowledgements}

The authors thank Zhiwei Zhang for assistance in the bioassays and Huey Min Tan for assistance in the LC-MS/MS analysis of the samples. They also thank Siew-Hong Low of the National University of Singapore for supervising the fieldwork of the Singapore Chinese Health Study and Kazuko Arakawa and Renwei Wang for developing the cohort study database. They acknowledge Mimi C Yu - the founding, long-standing Principal Investigator of the Singapore Chinese Health Study.

\section{References}

Baglietto L, Severi G, English DR, Krishnan K, Hopper JL, McLean C, Morris HA, Tilley WD \& Giles GG 2010 Circulating steroid hormone levels and risk of breast cancer for postmenopausal women. Cancer Epidemiology, Biomarkers \& Prevention 19 492-502. (doi:10.1158/1055-9965. EPI-09-0532)

Bernstein L, Yuan JM, Ross RK, Pike MC, Hanisch R, Lobo R, Stanczyk F, Gao YT \& Henderson BE 1990 Serum hormone levels in premenopausal Chinese women in Shanghai and white women in Los Angeles: results from two breast cancer case-control studies. Cancer Causes \& Control 1 51-58. (doi:10.1007/BF00053183)

Diamanti-Kandarakis E, Bourguignon JP, Giudice LC, Hauser R, Prins GS Soto AM, Zoeller RT \& Gore AC 2009 Endocrine-disrupting chemicals: an Endocrine Society scientific statement. Endocrine Reviews 30 293-342. (doi:10.1210/er.2009-0002)

Djiogue S, Njamen D, Halabalaki M, Kretzschmar G, Beyer A, Mbanya JC Skaltsounis AL \& Vollmer G 2010 Estrogenic properties of naturally occurring prenylated isoflavones in U2OS human osteosarcoma cells: structure-activity relationships. Journal of Steroid Biochemistry and Molecular Biology 120 184-191. (doi:10.1016/j.jsbmb.2010.04.014)

Du G, Shen O, Sun H, Fei J, Lu C, Song L, Xia Y, Wang S \& Wang X 2010 Assessing hormone receptor activities of pyrethroid insecticides and their metabolites in reporter gene assays. Toxicological Sciences 116 58-66. (doi:10.1093/toxsci/kfq120)

Early Breast Cancer Trialists' Collaborative Group 1992 Systemic treatment of early breast cancer by hormonal, cytotoxic, or immune therapy. 133 randomised trials involving 31,000 recurrences and 24,000 deaths among 75,000 women. Lancet 339 71-85.

Eliassen AH, Missmer SA, Tworoger SS \& Hankinson SE 2006 Endogenous steroid hormone concentrations and risk of breast cancer: does the association vary by a woman's predicted breast cancer risk? Journal of Clinical Oncology 24 1823-1830. (doi:10.1200/JCO.2005.03.7432)

Esslimani-Sahla M, Simony-Lafontaine J, Kramar A, Lavaill R, Mollevi C, Warner M, Gustafsson J-A \& Rochefort H 2004 Estrogen receptor $\beta$ (ER $\beta$ ) level but not its ER $\beta$ cx variant helps to predict tamoxifen resistance in breast cancer. Clinical Cancer Research 10 5769-5776. (doi:10.1158/ 1078-0432.CCR-04-0389)
Fang H, Tong W, Perkins R, Soto AM, Prechtl NV \& Sheehan DM 2000 Quantitative comparisons of in vitro assays for estrogenic activities. Environmental Health Perspectives 108 723-729. (doi:10.1289/ehp. 00108723)

Farhat GN, Cummings SR, Chlebowski RT, Parimi N, Cauley JA, Rohan TE, Huang AJ, Vitolins M, Hubbell FA, Manson JE et al. 2011 Sex hormone levels and risks of estrogen receptor-negative and estrogen receptorpositive breast cancers. Journal of the National Cancer Institute $\mathbf{1 0 3}$ 562-570. (doi:10.1093/jnci/djr031)

Fourkala EO, Zaikin A, Burnell M, Gentry-Maharaj A, Ford J, Gunu R, Soromani C, Hasenbrink G, Jacobs I, Dawnay A et al. 2012 Association of serum sex steroid receptor bioactivity and sex steroid hormones with breast cancer risk in postmenopausal women. Endocrine-Related Cancer 19 137-147. (doi:10.1530/ERC-11-0310)

Hankin JH, Stram DO, Arakawa K, Park S, Low SH, Lee HP \& Yu MC 2001 Singapore Chinese Health Study: development, validation, and calibration of the quantitative food frequency questionnaire. Nutrition and Cancer 39 187-195. (doi:10.1207/S15327914nc392_5)

Henderson BE \& Feigelson HS 2000 Hormonal carcinogenesis. Carcinogenesis 21 427-433. (doi:10.1093/carcin/21.3.427)

Hjelmborg PS, Ghisari M \& Bonefeld-Jorgensen EC 2006 SPE-HPLC purification of endocrine-disrupting compounds from human serum for assessment of xenoestrogenic activity. Analytical and Bioanalytical Chemistry 385 875-887. (doi:10.1007/s00216-006-0463-9)

Hopp TA, Weiss HL, Parra IS, Cui Y, Osborne CK \& Fuqua SA 2004 Low levels of estrogen receptor $\beta$ protein predict resistance to tamoxifen therapy in breast cancer. Clinical Cancer Research 10 7490-7499. (doi:10.1158/1078-0432.CCR-04-1114)

Iwasaki M, Inoue M, Otani T, Sasazuki S, Kurahashi N, Miura T, Yamamoto S, Tsugane S \& Japan Public Health Center-based prospective study group 2008 Plasma isoflavone level and subsequent risk of breast cancer among Japanese women: a nested case-control study from the Japan Public Health Center-based prospective study group. Journal of Clinical Oncology 26 1677-1683. (doi:10.1200/JCO.2007.13.9964)

Kaaks R, Rinaldi S, Key TJ, Berrino F, Peeters PH, Biessy C, Dossus L, Lukanova A, Bingham S, Khaw KT et al. 2005 Postmenopausal serum androgens, oestrogens and breast cancer risk: the European prospective investigation into cancer and nutrition. Endocrine-Related Cancer 12 1071-1082. (doi:10.1677/erc.1.01038)

Kabuto M, Akiba S, Stevens RG, Neriishi K \& Land CE 2000 A prospective study of estradiol and breast cancer in Japanese women. Cancer Epidemiology, Biomarkers \& Prevention 9 575-579.

Kandaraki E, Chatzigeorgiou A, Livadas S, Palioura E, Economou F, Koutsilieris M, Palimeri S, Panidis D \& Diamanti-Kandarakis E 2011 Endocrine disruptors and polycystic ovary syndrome (PCOS): elevated serum levels of bisphenol A in women with PCOS. Journal of Clinical Endocrinology and Metabolism 96 E480-E484. (doi:10.1210/jc.20101658)

Kanno Y, Okada H, Kobayashi T, Takenaka T \& Suzuki H 2007 Effects of endocrine disrupting substance on estrogen receptor gene transcription in dialysis patients. Therapeutic Apheresis and Dialysis 11 262-265. (doi:10.1111/j.1744-9987.2007.00472.x)

Key T, Appleby P, Barnes I, Reeves G \& Endogenous Hormones and Breast Cancer Collaborative Group 2002 Endogenous sex hormones and breast cancer in postmenopausal women: reanalysis of nine prospective studies. Journal of the National Cancer Institute 94 606-616. (doi:10.1093/jnci/94.8.606)

Key TJ, Appleby PN, Reeves GK, Roddam A, Dorgan JF, Longcope C, Stanczyk FZ, Stephenson HE, Falk RT, Miller R et al. 2003 Body mass index, serum sex hormones, and breast cancer risk in postmenopausal women. Journal of the National Cancer Institute 95 1218-1226. (doi:10.1093/jnci/djg022)

Key TJ, Appleby PN, Reeves GK, Roddam AW, Helzlsouer KJ, Alberg AJ, Rollison DE, Dorgan JF, Brinton LA, Overvad K et al. 2011 Circulating sex hormones and breast cancer risk factors in postmenopausal women: 
reanalysis of 13 studies. British Journal of Cancer 105 709-722. (doi:10.1038/bjc.2011.254)

Koh W-P, Yuan J-M, Sun C-L, van den Berg D, Seow A, Lee H-P \& Yu MC 2003 Angiotensin I-converting enzyme (ACE) gene polymorphism and breast cancer risk among Chinese women in Singapore. Cancer Research 63 573-578.

Kohno H, Gandini O, Curtis SW \& Korach KS 1994 Anti-estrogen activity in the yeast transcription system: estrogen receptor mediated agonist response. Steroids 59 572-578. (doi:10.1016/0039-128X(94)90050-7)

Kruger T, Spano M, Long M, Eleuteri P, Rescia M, Hjelmborg PS, Manicardi GC, Bizzaro D, Giwercman A, Toft G et al. 2008 Xenobiotic activity in serum and sperm chromatin integrity in European and Inuit populations. Molecular Reproduction and Development 75 669-680. (doi:10.1002/mrd.20747)

Langley MS, Hammond GL, Bardsley A, Sellwood RA \& Anderson DC 1985 Serum steroid binding proteins and the bioavailability of estradiol in relation to breast diseases. Journal of the National Cancer Institute $\mathbf{7 5}$ 823-829.

Lee GS, Choi KC, Kim HJ \& Jeung EB 2004 Effect of genistein as a selective estrogen receptor $\beta$ agonist on the expression of Calbindin-D9k in the uterus of immature rats. Toxicological Sciences 82 451-457. (doi:10.1093/toxsci/kfh296)

Li J, Lee L, Gong Y, Shen P, Wong SP, Wise SD \& Yong EL 2009 Bioassays for estrogenic activity: development and validation of estrogen receptor $(\mathrm{ER} \alpha / \mathrm{ER} \beta)$ and breast cancer proliferation bioassays to measure serum estrogenic activity in clinical studies. Assay and Drug Development Technologies 7 80-89. (doi:10.1089/adt.2008.154)

Lim VW, Li J, Gong Y, Yuan JM, Wu TS, Hammond GL, Jin A, Koh WP \& Yong EL 2012 Serum free estradiol and estrogen receptor- $\alpha$ mediated activity are related to decreased incident hip fractures in older women. Bone 50 1311-1316. (doi:10.1016/j.bone.2012.03.006)

Manjer J, Johansson R, Berglund G, Janzon L, Kaaks R, Agren A \& Lenner P 2003 Postmenopausal breast cancer risk in relation to sex steroid hormones, prolactin and SHBG (Sweden). Cancer Causes \& Control 14 599-607. (doi:10.1023/A:1025671317220)

Missmer SA, Eliassen AH, Barbieri RL \& Hankinson SE 2004 Endogenous estrogen, androgen, and progesterone concentrations and breast cancer risk among postmenopausal women. Journal of the National Cancer Institute 96 1856-1865. (doi:10.1093/jnci/djh336)

Nagata C, Nagao Y, Yamamoto S, Shibuya C, Kashiki Y \& Shimizu H 2008 Light exposure at night, urinary 6-sulfatoxymelatonin, and serum estrogens and androgens in postmenopausal Japanese women. Cancer Epidemiology, Biomarkers \& Prevention 17 1418-1423. (doi:10.1158/ 1055-9965.EPI-07-0656)

National Registry of Diseases Office 2008 Singapore Cancer Registry Report No 7: Trends in Cancer Incidence in Singapore 1968-2007. Singapore: Health Promotion Board.
Nelson RE, Grebe SK, OKane DJ \& Singh RJ 2004 Liquid chromatographytandem mass spectrometry assay for simultaneous measurement of estradiol and estrone in human plasma. Clinical Chemistry 50 373-384. (doi:10.1373/clinchem.2003.025478)

Probst-Hensch NM, Pike MC, McKean-Cowdin R, Stanczyk FZ, Kolonel LN \& Henderson BE 2000 Ethnic differences in post-menopausal plasma oestrogen levels: high oestrone levels in Japanese-American women despite low weight. British Journal of Cancer 82 1867-1870. (doi:10.1054/bjoc.1999.1082)

Rao J, Jiang X, Wang Y \& Chen B 2011 Advances in the understanding of the structure and function of ER- $\alpha 36$, a novel variant of human estrogen receptor- $\alpha$. Journal of Steroid Biochemistry and Molecular Biology 127 231-237. (doi:10.1016/j.jsbmb.2011.08.004)

Russo J \& Russo IH 2006 The role of estrogen in the initiation of breast cancer. Journal of Steroid Biochemistry and Molecular Biology 102 89-96. (doi:10.1016/j.jsbmb.2006.09.004)

Shimizu H, Ross RK, Bernstein L, Pike MC \& Henderson BE 1990 Serum oestrogen levels in postmenopausal women: comparison of American whites and Japanese in Japan. British Journal of Cancer 62 451-453. (doi:10.1038/bjc.1990.316)

Siiteri PK 1987 Adipose tissue as a source of hormones. American Journal of Clinical Nutrition 45 277-282.

Skliris GP, Leygue E, Curtis-Snell L, Watson PH \& Murphy LC 2006 Expression of oestrogen receptor- $\beta$ in oestrogen receptor- $\alpha$ negative human breast tumours. British Journal of Cancer 95 616-626. (doi:10.1038/sj.bjc.6603295)

Widschwendter M, Lichtenberg-Frate H, Hasenbrink G, Schwarzer S, Dawnay A, Lam A, Menon U, Apostolidou S, Raum E, Stegmaier C et al. 2009 Serum oestrogen receptor $\alpha$ and $\beta$ bioactivity are independently associated with breast cancer: a proof of principle study. British Journal of Cancer 101 160-165. (doi:10.1038/sj.bjc.6605106)

Wong SP, Li J, Shen P, Gong Y, Yap SP \& Yong EL 2007 Ultrasensitive cell-based bioassay for the measurement of global estrogenic activity of flavonoid mixtures revealing additive, restrictive, and enhanced actions in binary and higher order combinations. Assay and Drug Development Technologies 5 355-362. (doi:10.1089/adt. 2007.056)

Wu AH \& Pike MC 1995 Dietary soy protein and hormonal status in females. American Journal of Clinical Nutrition 62 151-153.

Wu AH, Koh WP, Wang R, Lee HP \& Yu MC 2008 Soy intake and breast cancer risk in Singapore Chinese Health Study. British Journal of Cancer 99 196-200. (doi:10.1038/sj.bjc.6604448)

Zeleniuch-Jacquotte A, Shore RE, Koenig KL, Akhmedkhanov A, Afanasyeva Y, Kato I, Kim MY, Rinaldi S, Kaaks R \& Toniolo P 2004 Postmenopausal levels of oestrogen, androgen, and SHBG and breast cancer: long-term results of a prospective study. British Journal of Cancer 90 153-159. (doi:10.1038/sj.bjc.6601517)

Received in final form 4 December 2013

Accepted 9 December 2013

Made available online as an Accepted Preprint

9 December 2013 http://erc.endocrinology-journals.org

DOI: 10.1530/ERC-13-0233
(C) 2014 Society for Endocrinology Printed in Great Britain
Published by Bioscientifica Ltd. 